\title{
COMMUNAL SPACE IN ISLAMIC ACTIVITY OF DUKUH KRAJAN, DESA KROMENGAN, KABUPATEN MALANG
}

Sri Winarni

Galih Widjil Pangarsa

Antariksa

Lisa Dwi Wulandari
Post graduates student-Built Environment Architecture

Brawijaya University, Malang, Indonesia

e-mail:wi2n_mlg27@yahoo.com

Master and Doctorate Programe

Brawijaya University, Malang, Indonesia

Master and Doctorate Programe

Brawijaya University, Malang, Indonesia

Master and Doctorate Programe

Brawijaya University, Malang, Indonesia

\begin{abstract}
Dukuh Krajan settlement is a one of the settlement that still hold and maintain the value of tradition, social and cultural in the daily and social life. Nowadays, the phenomena that happens in the social-cultural community is the decrement of life pattern of the rural community consist of the value of togetherness and mutual cooperation. This transformation will affect changes of common space. It still needs a deeper research about the formed common spaces especially in the relation with Islamic activity in regular nor incidentally basis. With purpose so that the formed common space can be benficial to grow some communal senses and mutual cooperation in the next generation. The research using qualitative with rationalistic approach. With the data acquired from the filed observation and interview with social figure and the residence. Common space is a common area that formed from the participation of the residence. Space as a base of common life grow from the alliance by building those spaces for a joint interest. the physical room of the Islamic activity consist of two namely residence house Islamic activity and public facility Islamic activity. Those function can transform when the Islamic activity being held. Semi public spaces, semi private, and private will change into common space function. This is affected by the activity, user, time and the room atribute inside. The space application of one activity has a sequence which give the activity and the user a interpretation, in this case togetherness and communality.
\end{abstract}

Keywords: Common Space, Islamic Activity, Rural Settlement

\begin{abstract}
Abstrak
Permukiman Dukuh Krajan merupakan salah satu pedesaan yang masih memegang dan mempertahankan nilainilai tradisi, sosial dan budaya baik dalam kehidupan sehari-hari maupun kehidupan sosial. Dalam kehidupan sosial-budaya masyarakat desa saat ini corak kehidupan masyarakat desa yang berupa nilai-nilai kebersamaan dan kegotong-royongan semakin menipis. Perubahan ini akan berpengaruh juga terhadap perubahan ruangruang komunal. Untuk itu perlu diteliti lebih mendalam tentang ruang komunal yang terbentuk khususnya dalam kegiatan keislaman. Dengan tujuan agar ruang komunal yang terbentuk dapat bermanfaat untuk kepentingan sosial dan eksistensinya tetap ada dan terjaga dengan baik serta dapat bermanfaat dalam menumbuhkan rasa kebersamaan dan kegotong-royongan pada generasi berikutnya. Metode yang digunakan adalah metode penelitian kualitatif dengan pendekatan rasionalistik. Dengan data-data diperoleh dari observasi lapangan dan wawancara dengan tokoh masyarakat dan masyarakat umum setempat. Ruang komunal merupakan ruang bersama yang terbentuknya atas dasar partisipasi warga. Keruangan yang menjadi dasar dalam kehidupan bersama ditumbuhkan melalui kebersamaan dengan membuat ruang-ruang tersebut untuk kepentingan bersama. Ruang kegiatan keislaman fisik terbagi menjadi dua tempat yaitu kegiatan keislaman di tempat hunian warga dan kegiatan keislaman di fasilitas umum. Pada saat pelaksanaan kegiatan keislaman fisik ruang tersebut akan mengalami perubahan menjadi ruang komunal. Hal ini dipengaruhi oleh kegiatan atau aktivitas, pelaku, waktu, dan atribut ruang yang ada di dalamnya. Penggunaan ruang dalam suatu kegiatan memiliki suatu rangkaian yang menjadikan kegiatan dan pelakunya mempunyai makna, yaitu makna kebersamaan dan keguyuban.
\end{abstract}

Kata Kunci: Ruang Komunal,Kegiatan Keislaman, Pemukiman Pedesaan 


\section{Introduction}

Villagers mostly identical with agraric lifestyle rely on livehood systems, farming life either with fields or plantations. Their life also based from a tight sense of kinship. A community is a "gameinschaft" which have a strong sense of mutual cooperation. Rural community has a face to face group as an character, they recognize each other as they recognize themselves ${ }^{1}$.

Nowadays, the phenomena that happens in the social-cultural community is the decrement of life pattern of the rural community consist of the value of togetherness and mutual cooperation. This transformation will affect the changes of common space. Common space or communal overcome as beneficial room fit for mutual interest recognized by member of the owner. This Common space has a kami value ${ }^{2}$. The actor of the common space has a sense of ownership, especially in the kinship with each other, either in blood relations (relatives) or in the social bond like a family.

This research take a case study in rural settlement in Dukuh Krajan, Desa Kromengan, Kabupaten Malang. Dukuh Krajan settlement is still holding their traditional, social and cultural dignity inherited from each generations. The pattern of a common space is especially formed in the profession activity that still needs a deeper research in the formed common spaces especially in the relation with Islamic activity in regular nor incidentally basis. With purpose so that the formed common space can be benficial to grow some communal senses and mutual cooperation in the next generation. The Dukuh Krajan research only covers RW 5, 6 and 7 areas since there are the center of the Dukuh Krajan activity, i.e The main government district levels, the main government village levels (village office), and trading center as market and surrounding ricefields and plantation.

\section{Research Method}

The research using qualitative with rationalistic approach. The data is acquired from the filed observation and interview with social figure and the residence. Common space is a common area that is formed from the participation of the residence. The description of the existing condition mainly from a various mould aspect of settlement and analyze various factors behind those particular phenomenon.

\section{Analysis Result and Discussion}

Desa Kromengan is a rural settlement located in southern Gunung Kawi slope, in Kecamatan Kromengan, Kabupaten Malang. According to interview with a local figure, in the past, this village is built at 3 centuries ago, approximately in the year of 1700. At that time, Desa Kromengan area is still in the form of unhabited forest. Then come a troupe consist of five fair siblings from Mataram Kingdom East Java, tripe a pedestal and clearing the area, so the settlement formed, until their descendant keep building and develop the village until these day ${ }^{3}$.

The Java and Islamic aculturatic culture still attached in the society, the culture activity that is related with Java/Islamic calendar like a nyadran culture, nikahan, slametan, tahlilan, sayan, mithoni etc. The settlement of Desa Kromengan is surrounded by ricefield area and plantation. Moreover in village settlement also have a village institution, agricultural group, village religion and art. Desa Kromengan settlement consist of three region; Dukuh Ringinanom, Dukuh Krajan, Dukuh Balkon. From each of the dukuh, Dukuh Krajan is the main village government, main sub district government and economic source. Dukuh Krajan has a special characteristic representative enough from all of the dukuh in Dukuh Krajan. (Picture 1 and Picture 2)

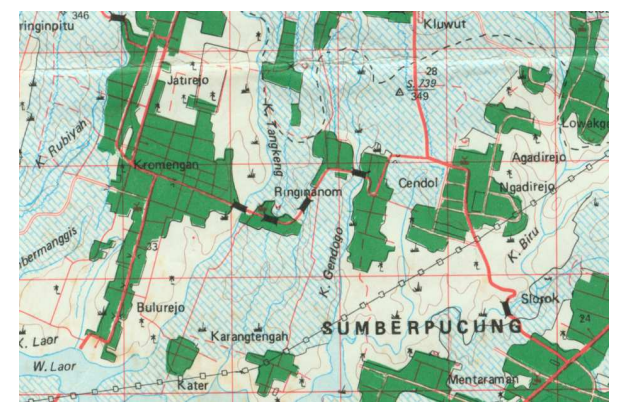

Picture 2. Map of Desa Kromengan Region

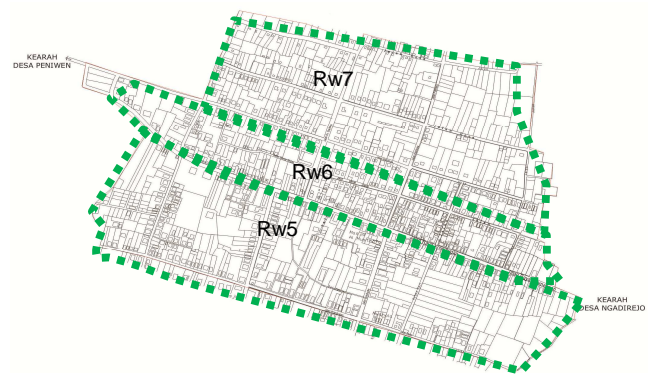

Picture 3. Location Map of Dukuh Krajan RW5,6 and 7

Krajan Islamic Activity Cases in Dukuh Krajan

Cultural activity of dukuh Krajan society is potrayed by the usage of Java/Islamic calendar system. This can be shown in the islamic activity in Dukuh Krajan. Islamic activity like tahlilan and routine thiba', five time pray, TPQ and general 
recitation and big worship in a Islamic feast day (Idul Adha praying and sacrificial qurban animal). Based from the time the cases divided in three activities:

\section{Daily Islamic Activity_Five Times Pray Worship and TPQ Recitation}

According to the interview and observation result in Dukuh Krajan, the activities consist of five time pray which done in the morning subuh prayer, afternoon maghrib prayer and night isya prayer but the participant consist only from elderly. The second is TPQ recitation, this activity initiated with ashar prayer continued with TPQ recitation with 5-10 years old kids. This is a formal activity, with high intensity of beneficial room usage because this regular daily activity. The room setting in TK Muslimat, mushola and mosque scattered in RW 5, 6 and 7. Actor activity divided into two activity, the TPQ recitation with approximately 6-10 people capacity, sometimes more than that. In five time prayer only consist of 58 gentlemen and ladies. The range from the observation result in mosque area, musholla and TPQ approximately $7.00 \mathrm{~m}-1 \mathrm{~km}$ from each of housing unite concludes medium range distance. The room element and atribute used by the society conducting five time prayer and TPQ recitation as shown in Picture 4-6 and Table 1.

Table 1. Space Elements

\begin{tabular}{ccc}
\hline $\begin{array}{c}\text { Fixed } \\
\text { element }\end{array}$ & $\begin{array}{c}\text { Semi fixed } \\
\text { element }\end{array}$ & Non fixed element \\
\hline $\begin{array}{c}\text { Brick wall, } \\
\text { door fence }\end{array}$ & $\begin{array}{c}\text { Chair, table, } \\
\text { black board }\end{array}$ & $\begin{array}{c}\text { - } \\
\text { The kids gathering in } \\
\text { the mosque yard, inner } \\
\text { mosque room, TK and } \\
\text { TK yard. }\end{array}$ \\
\hline $\begin{array}{c}\text { Brick wall, } \\
\text { door fence }\end{array}$ & Mat, room & $\begin{array}{l}\text { People gathering and } \\
\text { partition }\end{array}$ \\
& & $\begin{array}{l}\text { create common space } \\
\text { in mosque foyer and } \\
\text { mosque prayer area }\end{array}$ \\
\hline
\end{tabular}

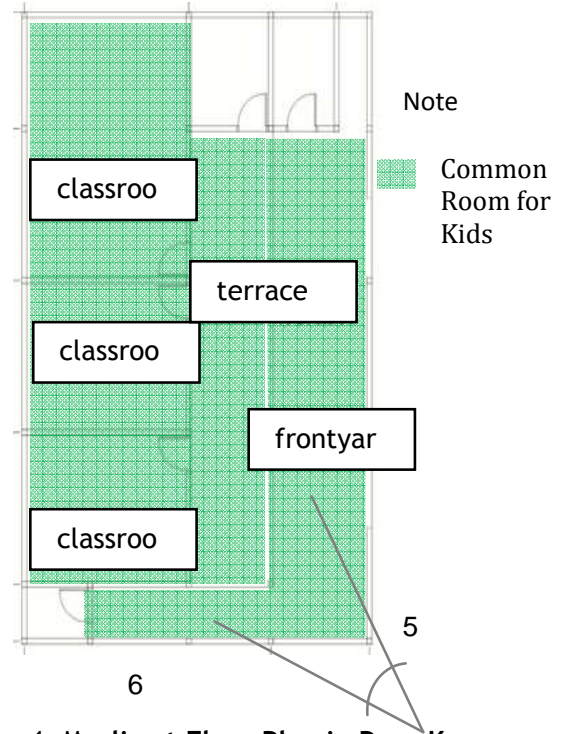

Picture 4. Muslimat Floor Plan in Desa Kromengan

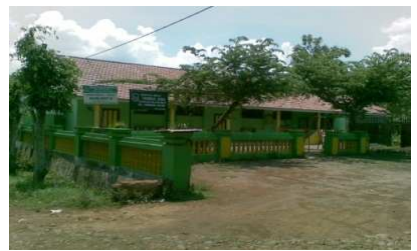

Picture 5 Recite location in TPQ

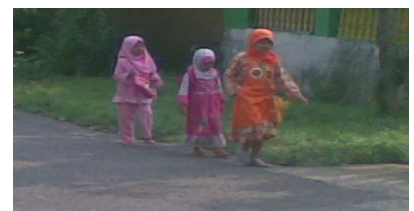

Picture 6. Kids going to the TPQ

The daily Islamic activity mostly using public activity in the operation. This public facility are not become a magnet to the forming of common space. This public facility becames a common space in daily joint activities. The existing public facility utilized for shared interest to make balanced environmetn in daily and social life, as stated Rapoport in Haryadi, 2010 that back ground, culture and user behaviour related to the activity. In this case the activity and lifestyle roled as determinant of spacial order. (Picture 7 and Picture 8)

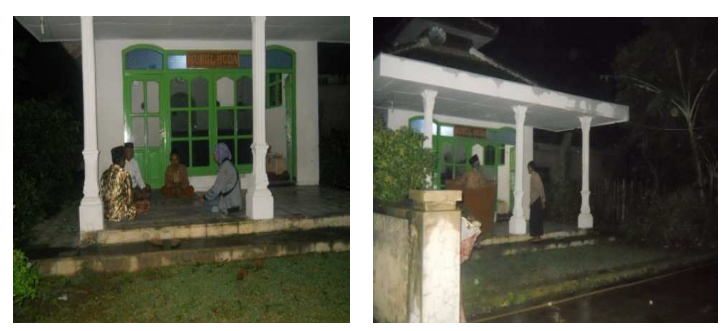

Picture 7 Islamic Discussion Activity and Congregational Prayer Setting
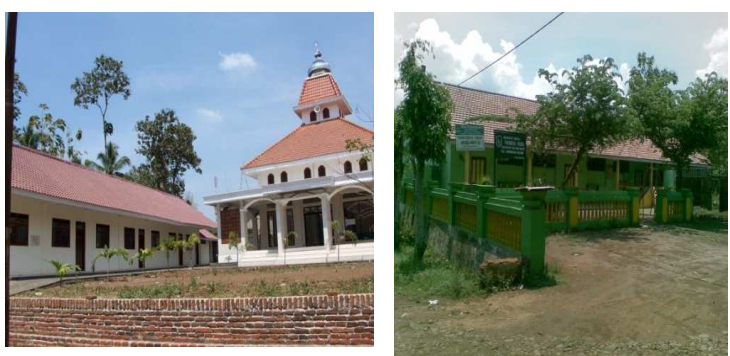

Picture 8. Islamic Mosque and TPQ Activity Setting

\section{Weekly Islamic Activity}

The first weekly Islamic activity is the cases of gentelemen tahlilan in Suliyadi's house. According to the interview this tahlilan event is aided by the neighborhood from the cooking activity until the 
food contribution from the neighbour. This tahlilan activity held regularly which turns by a house number, not by social gathering and voluntary contribution only.

The second Islamic activity is a routine ladies tahlilan, and one who got the host turns is in Agus Swadio's house. Based from the interview this tahlilan supported by the neoghborhood from helping in the kitchen until the food preparation contribution. This tahlilan routine activity held by the way of social gathering (arisan), whoever gets the honour as a host to the next tahlilan event.

The third islamic activity is tiba'an, this routine activity held in one of teenage house in the house of Sukri family. This tiba'an activity held in turns in the way of social gathering (arisan), and the event is similiar with the ladies tahlilan. The nature of this event is formal with high intensity of the room usage because this event held weekly. Gentlemen hold 40 people capacity, ladies 60 people capacity and teenage tiba'an 30 people or more. The range of the distance, based from observation is $7.00 \mathrm{~m}-1 \mathrm{~km}$ from each house unite and concluded as a medium range because of the large land owning in the village. Each of the house phisycal room consist of guest room, family room, foyer and the kitchen. The room element or the atribute used as follows (Table 2)

Table 2 Space Elements

\begin{tabular}{|c|c|c|c|}
\hline Location & $\begin{array}{c}\text { Fixed } \\
\text { Element }\end{array}$ & $\begin{array}{c}\text { Semi } \\
\text { Fixed } \\
\text { Element }\end{array}$ & $\begin{array}{l}\text { Non Fixed } \\
\text { Element }\end{array}$ \\
\hline $\begin{array}{l}\text { Tahlilan } \\
\text { residence }\end{array}$ & $\begin{array}{l}\text { Brick } \\
\text { wall, } \\
\text { door } \\
\text { fence }\end{array}$ & $\begin{array}{c}\text { Mat, Tahlil } \\
\text { book, } \\
\text { tiba'an }\end{array}$ & $\begin{array}{l}\text { - People } \\
\text { gathering and } \\
\text { create a } \\
\text { common space } \\
\text { in foyer, guest } \\
\text { room and } \\
\text { family room }\end{array}$ \\
\hline
\end{tabular}

The same vent participated weekly by the father, mother and the children was done regularly from each of the resident incorporated in recitation community. Stated by Robinson ${ }^{4}$ (2001), Haryadi ${ }^{5}$ about room characteristic, that in daily usage of the room is a common spatial, and will transform when the worship activity is held. That physical room can change to be a guest room, family room, kitchen and the bathroom/toilet, when that particular room will became a common space, the guest room became the event room, family room and kitchen to prepare the cuisine, and the bathroom/toilet became public when the tahlil member use that bathroom/toilet (Table 3).
Table 3. Daily Space When the Islamic Activity Held

\begin{tabular}{ll}
\multicolumn{1}{c}{ Room } & \multicolumn{1}{c}{ Worship activity } \\
Yard & Public/member communal \\
Foyer & Public/member communal \\
Guest Room & Semi Public/member communal \\
Family Room & Semi Public/member communal \\
Kitchen & Semi Public/member communal \\
Bathroom/Toilet & Semi Public/member communal \\
\hline
\end{tabular}

They set the wanted comfort, that they feel the host house where the recitation held can be beneficial for the new and regular member of that private area with rules, traditions and the custom habirs in their village. The village society already has a way to fix it by villagers hospitality and teposeliro in order to accept a newcomer in a social activity.

Based from the interview to the room that private room has its own comfort levels, but because of the togetherness and kinship factor between the neighbour, they don't really need a private room for their own private issue, except bedroom, which have a clear limit for individual (Picture 9).
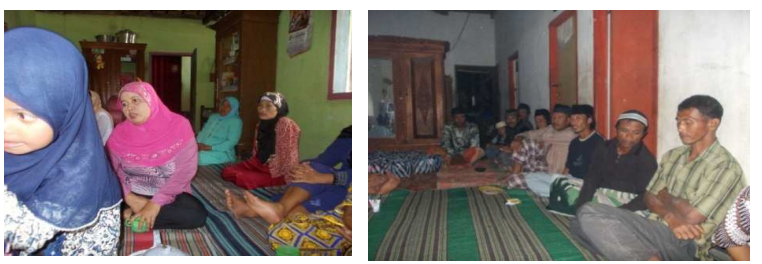

Picture 9. Weekly activity

The fourth weekly routine activity is Friday prayer done by the gentlemen, teenage boys and some of the ladies. There are many worship place especially used for Friday prayer such as mosques scattered in Dukuh Krajan, only in RW 5 and 7 area. The togethernes and reconciliation are clearly shows in this activity.

\section{Yearly Islamic Activity Yearly Recitation}

Yearly recitation held one day after nyadran and kirab desa event. This recitaion held in village hall pendopo participated by all of the Desa Kromengan residents consist of the fathers, mothers 
and the childrens. The activity composed by recitation and terbang jidor, this activity is formal with low intensity of room usage because the activity is yearly basis. The user capacity approximately around 50-100 people, or more. The distance range based from the observation is $>7.50 \mathrm{~m}$ from each of the house unites and concluded as a considerably far distance. The facility used in the common space is along the way of the front side of the district office, village hall and the room inside of it. The used room element or atribute as shown in Table 4.

Tabel 4. Room Elements

\begin{tabular}{lccl}
\hline Location & $\begin{array}{c}\text { Fixed } \\
\text { Element }\end{array}$ & $\begin{array}{c}\text { Semi Fixed } \\
\text { Element }\end{array}$ & $\begin{array}{l}\text { Non Fixed } \\
\text { Element }\end{array}$ \\
\hline $\begin{array}{l}\text { Alongsid } \\
\text { e road in } \\
\text { front of } \\
\text { village } \\
\text { hall and } \\
\text { the room } \\
\text { inside }\end{array}$ & $\begin{array}{c}\text { Concrete } \\
\text { fence, plant } \\
\text { fable, } \\
\text { partition }\end{array}$ & $\begin{array}{c}\text { Drink } \\
\text { place, } \\
\text { terbangan } \\
\text { musical } \\
\text { instrument }\end{array}$ & $\begin{array}{l}\text { People } \\
\text { gathering } \\
\text { to create } \\
\text { common } \\
\text { space in } \\
\text { the district } \\
\text { office }\end{array}$ \\
\hline
\end{tabular}

The common space usage mostly in all the room which use village component as the committee or the member is the common community. The village pendopo, yard and village office room formed as a room used to prepare all of the necessity of the recitation event, moreover the road in fron of the village office can also used as a common parking lot and sales activity. (Picture 10 - Picture 12)

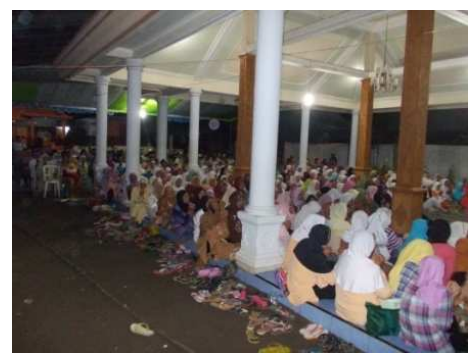

Picture 10. Yearly Recitation

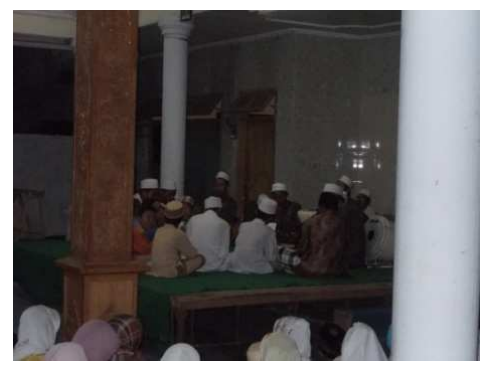

Picture 11. Terbangan Group
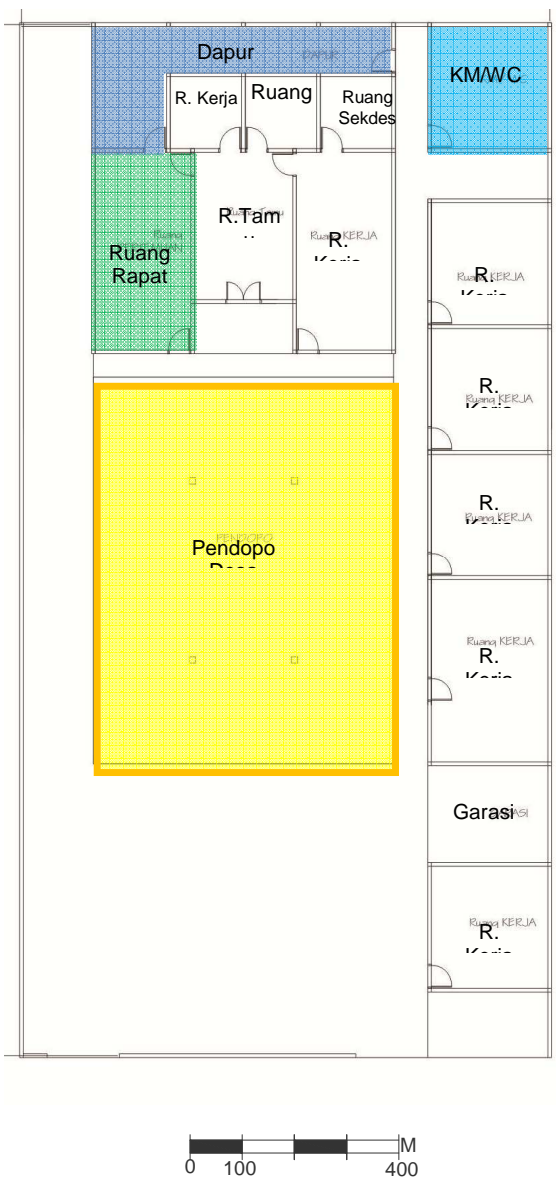

Description:

\begin{tabular}{ll}
\hline Room & $\begin{array}{l}\text { Common space } \\
\text { usage }\end{array}$ \\
\hline Meeting room & \\
Kitchen & \\
Bathroom & \\
Village hall &
\end{tabular}

Picture 12. Pendopo, Where the Event Take Place

\section{Islamic Feast Day Celebration}

In this research, the Islamic Feast Day Celebration activity consist of Idul Adha prayer and slaughter of the qurban animal. The nature of the event is formal with high intensity of room usage because this event held once in every year. The user capacity more or less than 30-40 people, or more. According to the observation, the distance range of this event approximately $7.50 \mathrm{~m}-1 \mathrm{~km}$ from each of the house unite and concluded as a medium distance. The room element and the atribute that used as shown in Table 5. 
Tabel 5. Room Elements

\begin{tabular}{|c|c|c|c|}
\hline Location & $\begin{array}{l}\text { Fixed } \\
\text { Element }\end{array}$ & $\begin{array}{c}\text { Semi } \\
\text { Fixed } \\
\text { Element }\end{array}$ & $\begin{array}{l}\text { Non Fixed } \\
\text { Element }\end{array}$ \\
\hline $\begin{array}{l}\text { Mosque } \\
\text { RW } 5 \text { and } \\
7\end{array}$ & $\begin{array}{c}\text { Concrete } \\
\text { fence, } \\
\text { plant } \\
\text { fence, } \\
\text { chair, } \\
\text { table }\end{array}$ & $\begin{array}{l}\text { Prayer } \\
\text { mat, mat, } \\
\text { partition }\end{array}$ & $\begin{array}{l}\text { People } \\
\text { gathering to } \\
\text { create common } \\
\text { space in mosque }\end{array}$ \\
\hline
\end{tabular}

The Idul Adha prayer held together and continued with the qurban animal slaughter activity. This yearly event physical room consist of the road in front of the mosque area. Based from the result of the observation and analysis that the usage of the religious room activity in Idul Adha feast day surpassed the mosque capacity limit, there's one residence whose house in one neighbourhood withthe mosque volunteered his yard as a prayer area, and theresident use public facility such as road because of the lack of prayer zone capacity. Apart to use the road as a prayer zone the committee also use the shoulder road as a slaughter area. (Picture 13-Picture 17)

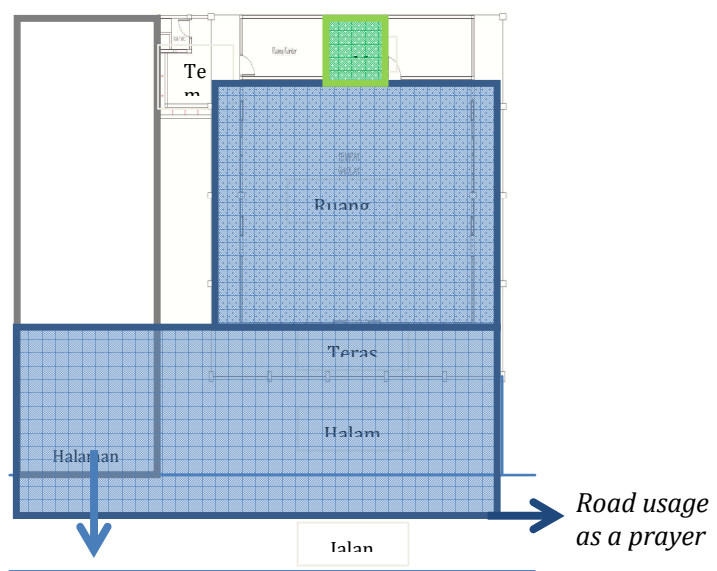

Yard usage as

a praver area

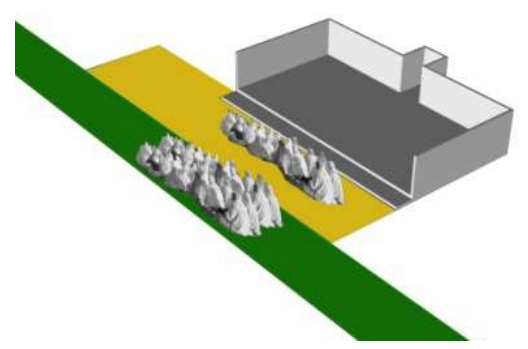

Picture 13. The Mosque Where Idul adha Prayer Held

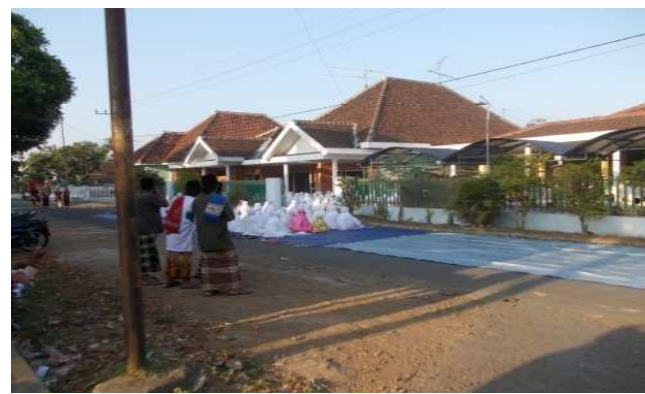

Picture 14. The Road that is Used as a Place of Prayer

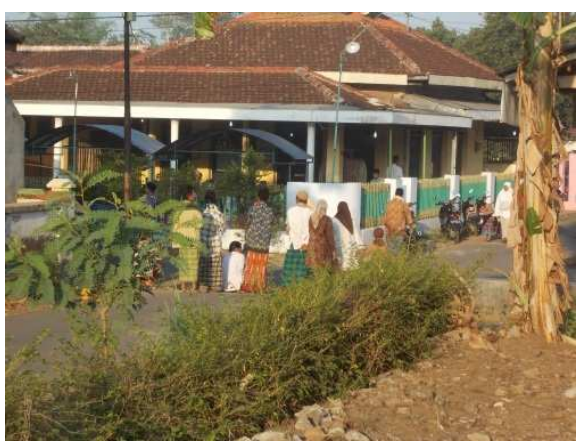

Picture 15. People Walked to the Mosque

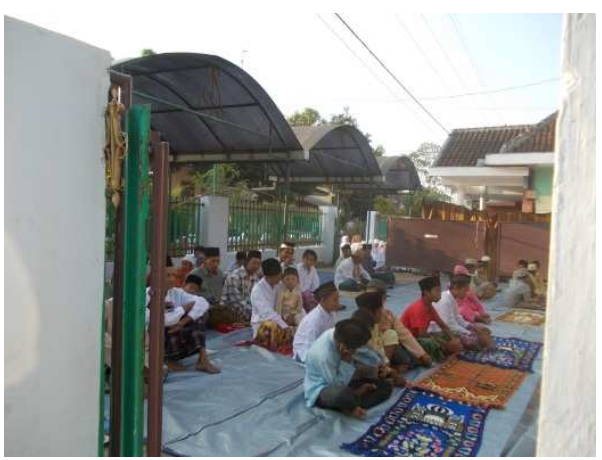

Picture 16. Praying in the Mosque Yard

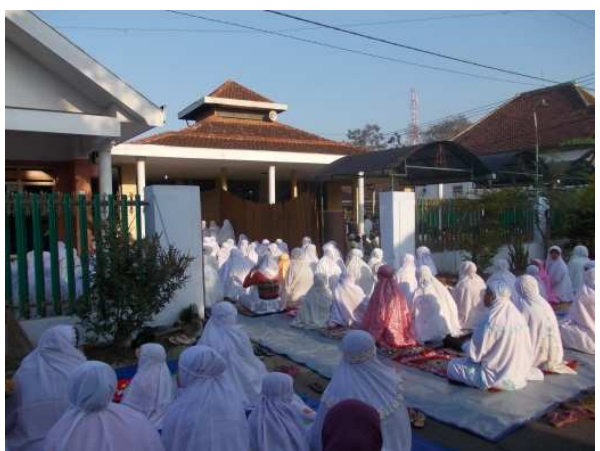

Picture 17. Praying in the Resident Yard and in the Road

This Islamic activity use more of the public facility in the process. The public facility is not only became a magnet to form the common space, but 
also became a common space itself for the Islamic society group.

\section{CONCLUSION}

Common space is a common area that is formed from the participation of the residence. Space as a base of common life grow from the alliance by building those spaces for a joint interest. This can reduce the effect of the social changing that cause excluded several local culture. From the upper description it can be concluded that the physical room of the Islamic activity consist of two namely residence house Islamic activity and public facility Islamic activity. In daily activity of the public domain, semi public domain, semi private domain and private domain already functioned properly, but those function can transform when the Islamic activity being held. Semi public spaces, semi private, and private will change into common space function. This is affected by the activity, user, time and the room atribute inside. The space application of one activity has a sequence which give the activity and the user a interpretation, in this case togetherness and communality.

\section{Reference}

1 Bintarto, R., 1989, Interaksi Desa dan Kota dan Permasalahannya. Jakarta: Ghalia Indonesia

2 Prijotomo,J., Widyarta, M.N., Hidayat, A., Adiyanto.,J, 2009. Ruang di Arsitektr Jawa: sebuah wacana, Surabaya: Wastu Lanas Grafika

3 Rencana Pembangunan Jangka Menengah Desa(RPJMD), 2010-2014 Desa Kromengan

4 Robinson, Julia W. 2001, Institutional Space, Domestic Space, and Power Relations: Revisiting territoriality with space syntax. 3rd International Space Syntax Symposium Atlanta.

5 Haryadi. 2010, Arsitektur, Lingkungan dan Perilaku.Yogyakarta: Gadjah Mada University Press. 